\title{
INFLUENCE OF SYNTHESIS FACTORS ON PROPERTIES OF GEOPOLYMERS BASED ON RED MUD AND RICE HUSK ASH
}

\author{
Tran Ngoc Tuyen ${ }^{1, *}$, Nguyen Duc Vu Quyen ${ }^{1}$, Ho Van Minh Hai ${ }^{1}$, \\ Dang Xuan Tin ${ }^{1}$, Tran Ngoc Quang ${ }^{2}$ \\ ${ }^{I}$ Department of Chemistry, College of Sciences, Hue University, 77 Nguyen Hue Str., Hue city \\ ${ }^{2}$ Department of Environmental Science, College of Sciences, Hue University, \\ 77 Nguyen Hue Str., Hue city \\ "Email: trntuyen@gmail.com
}

Received: 27 February 2017; Accepted for publication: 3 July 2017

\begin{abstract}
In this paper, the effect of mixing ratio of raw materials, curing temperature and time on geopolymerization between red mud and rice husk ash were investigated. The results showed that the optimum conditions were $\mathrm{SiO}_{2} / \mathrm{Al}_{2} \mathrm{O}_{3}$ ratio of 4 and $\mathrm{Na}_{2} \mathrm{O} / \mathrm{Al}_{2} \mathrm{O}_{3}$ ratio of 2.0 , curing temperature of $100{ }^{\circ} \mathrm{C}$ and curing time of 24 hours. The compressive strength, bulk density, total shrinkage of the obtained product were $22.8 \mathrm{MPa}, 2.39 \mathrm{~g} . \mathrm{cm}^{-3}, 15 \%$, respectively that met requirement of unsintered bricks using for construction.
\end{abstract}

Keywords: red mud, rice husk ash, geopolymerization.

\section{INTRODUCTION}

Geopolymer which is amorphous appears to be a potential alternative to the classic hydraulic binders. The exothermic reaction of geopolymerization generates a structure similar to zeolites [1] that is mainly produced from the reaction between metakaolin (source of $\mathrm{Si}$ and $\mathrm{Al}$ ) and hydroxides or alkaline silicate solutions [2, 3, 4]. According to D. Kim et al. [5], geopolymers can be classified into two major groups: (i) pure inorganic geopolymers and (ii) organic containing geopolymers. The geopolymerization mechanism involves $\mathrm{Si}$ and $\mathrm{Al}$ dissolution from the starting materials and forms available polysialate units (e.g., sialate [-Si-O$\mathrm{Al}-\mathrm{O}-]$, sialate siloxo [-Si-O-Al-O-Si-O-] or sialate disiloxo [-Si-O-Al-O-Si-O-], depending on the $\mathrm{Si} / \mathrm{Al}$ ratio) cross-linked $\left[\mathrm{AlO}_{4}\right]$ and $\left[\mathrm{SiO}_{4}\right]$ tetrahedral units, with charge balance ensured by $\mathrm{Na}^{+}$or $\mathrm{K}^{+}$ions [3]. Moreover, geopolymers have the advantage to be possibly formulated from a wide range of aluminosilicate minerals (e.g. fly ash, red mud, rice husk ash) [6 - 12]. This diversity in material sources places it as interesting solution for red mud incorporation.

Red mud (RM) is the major waste of the Bayer alumina extraction process from bauxite. The worldwide annual amount of RM is about 50 to 80 million tons [13]. In Vietnam, around 5.5 billion tons of bauxite is reserved in Taynguyen plateau. Therefore, many aluminum plants have 
been developed in this plateau in recent years. At the moment, Tanrai (Lamdong) and Nhanco (Daknong) alumina-plant emit approximately 650,000 tons of dry RM per year. The main compositions of RM consist of different forms of iron and aluminum oxide minerals, calcium aluminum silicates, sodium, etc. and a redundant alkaline amount, which are hazardous, strongly contaminates soil and groundwater, and destroys ecosystems. Therefore, much research has been performed to encourage reusing RM to produce valuable products, and hence minimize its damage to the environment. Nowadays, most studies of RM utilization, which mainly focus on certain fields such as arsenic adsorption from aqueous solution [14], glass-ceramics manufacturing [7], sintered bricks [15], steelmaking [16, 17], unsintered bricks [10, 11], iron, alumina and titanium oxide recovering [18, 13], , inorganic pigments [19], rare earths recovering [20], Portland cement clinker manufacturing [21], et., have been reported. However, research of the geopolymering process between RM and clay or fly ash in manufacturing unsintered bricks is highly concerned.

Rice husk ash (RHA) being common residue of agricultural production in Vietnam is also under research with the same aim. According to The Ministry of Agriculture and Rural Development data, Vietnam produced 45 million tons of rice in 2015 and was followed by approximately 9 million tons of rice husk that was combusted and released an estimated calorific value of around $3400 \mathrm{kcal}$ per $\mathrm{kg}$. Therefore, this massive amount of rice husk was mainly used as a combustible fuel. During the combustion, $25 \%(\mathrm{w} / \mathrm{w})$ of rice husk turns into ash mainly consisting of amorphous $\mathrm{SiO}_{2}$ (over $80 \%$ ) which is highly active and easily reacts with $\mathrm{Al}_{2} \mathrm{O}_{3}$ in $\mathrm{RM}$ through geopolymerization.

In the article, the manufacturing process of geopolymers from RM and RHA was investigated. In short, the effect of synthesis factors, i.e., material composition, curing time and temperature, on physico-mechanical properties of the obtained geopolymers was discussed.

\section{EXPERIMENTAL}

\subsection{Raw materials}

Red mud employed in this study was collected from the waste storage of Lam Dong aluminium plant producing alumina from Tanrai bauxite. The plant is located in Baolam district, Lam Dong province, Vietnam (Fig. 1). Rice hush ask (RHA) was residue of drying oven using rice husk, collected at Phongdien Prime Joint Stock Company, Thua Thien Hue province, Vietnam.

The RM and RHA were dried at $105{ }^{\circ} \mathrm{C}$ for $24 \mathrm{~h}$, grinded using ball mill, and sieved through a mesh (the diameter of the mesh is $0.154 \mathrm{~mm}$ ).

\subsection{Preparation of geopolymers}

The manufacturing process of geopolymers from RM and RHA is shown in Fig. 2. In detail, RM, RHA, NaOH $99 \%$ (Guangzhou, China) and water were mixed into wet mixtures (humidity of around $30 \%$ ) consisting of $\mathrm{SiO}_{2}, \mathrm{Al}_{2} \mathrm{O}_{3}$ and $\mathrm{Na}_{2} \mathrm{O}$ with different molar ratios from 3.0 to 6.0 for $\mathrm{SiO}_{2} / \mathrm{Al}_{2} \mathrm{O}_{3}$ and 1.0 to 2.5 for $\mathrm{Na}_{2} \mathrm{O} / \mathrm{Al}_{2} \mathrm{O}_{3}$. The obtained mixtures were shaped into masses using wooden molds with dimensions of $4 \times 4 \times 4 \mathrm{~cm}^{3}$. Green bodies were at room temperature and different temperatures ranging from $100{ }^{\circ} \mathrm{C}$ to $200{ }^{\circ} \mathrm{C}$. Sample notations and their initial compositions are illustrated in Table 1. 


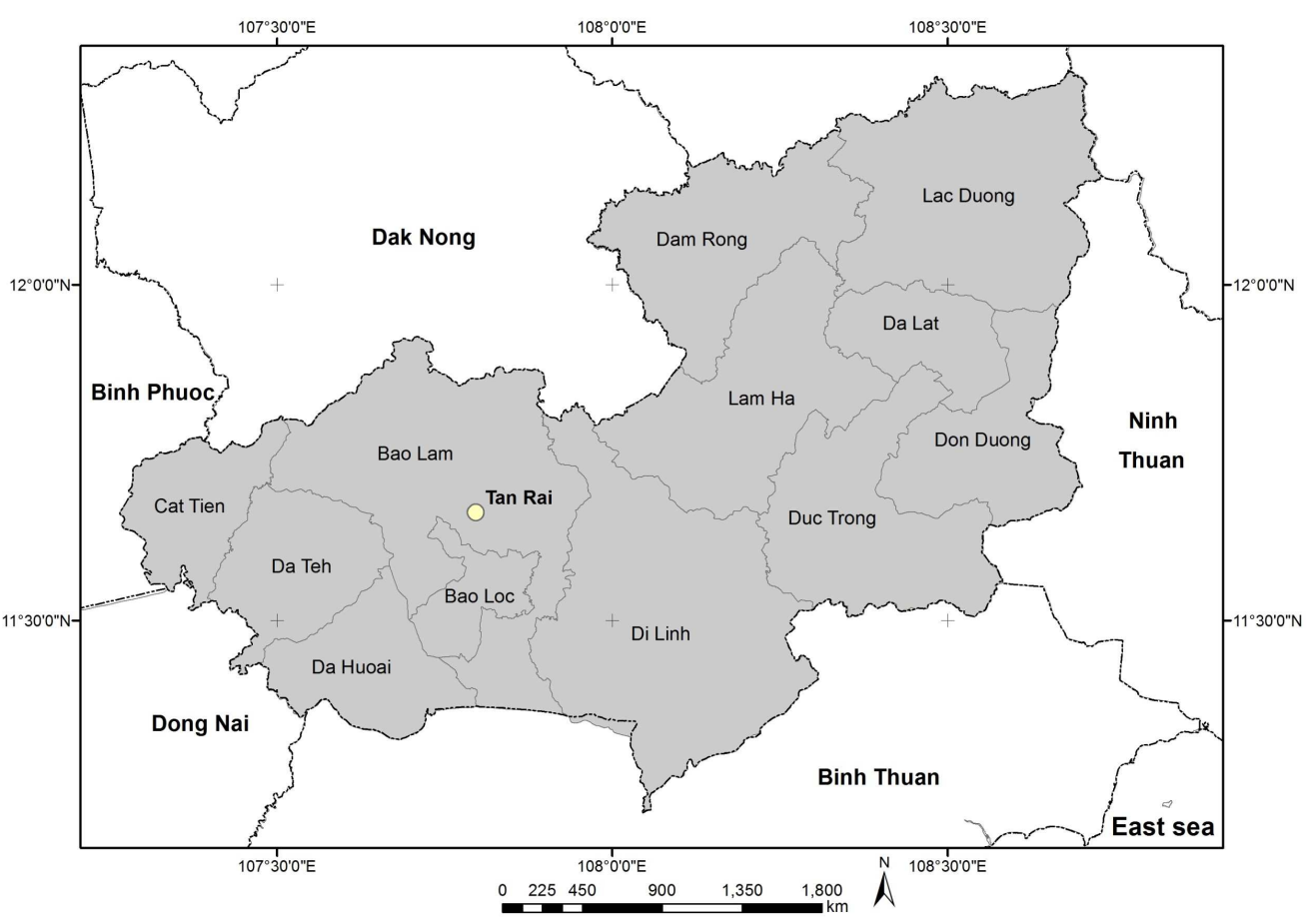

Figure 1. Bao Lam district map.

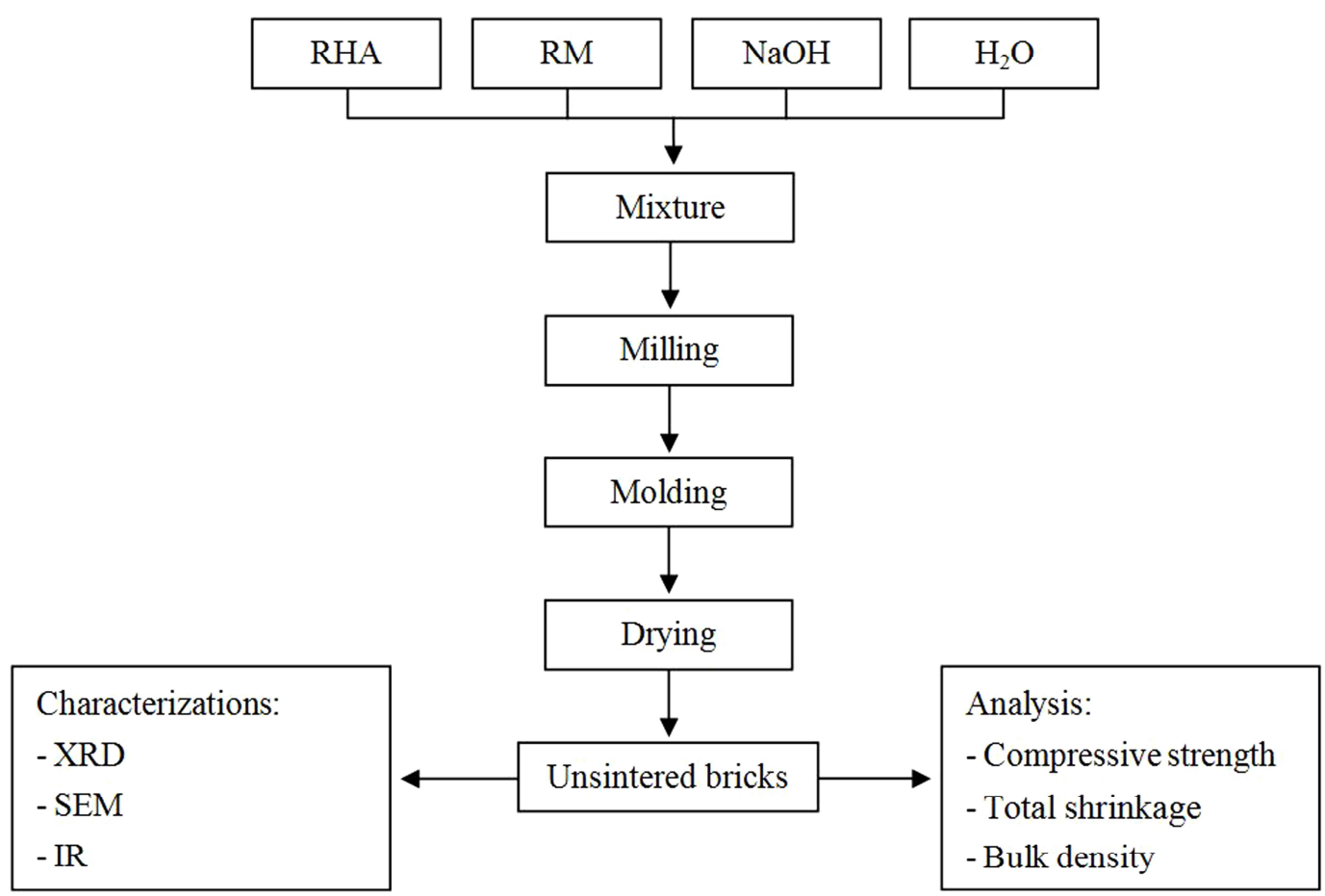

Figure 2. Schematic diagram of production of geopolymers. 
Table 1. Initial composition of samples.

\begin{tabular}{|c|c|c|c|c|c|c|}
\hline \multirow{2}{*}{ Notation } & \multirow{2}{*}{$\begin{array}{c}\text { Molar ratio of } \\
\mathrm{SiO}_{2} / \mathrm{Al}_{2} \mathrm{O}_{3}\end{array}$} & $\begin{array}{c}\text { Molar ratio of } \\
\mathrm{Na}_{2} \mathrm{O}_{2} \mathrm{Al}_{2} \mathrm{O}_{3}\end{array}$ & \multicolumn{4}{|c|}{ Percentage composition (w/w) } \\
\cline { 5 - 7 } & 3.0 & 1.0 & 49.1 & 16.3 & 4.6 & 30.0 \\
\hline M3-1.0 & 3.0 & 1.5 & 46.6 & 15.5 & 7.8 & 30.0 \\
\hline M3-2.0 & 3.0 & 2.0 & 44.4 & 14.8 & 10.8 & 30.0 \\
\hline M3-2.5 & 3.0 & 2.5 & 42.4 & 14.1 & 13.5 & 30.0 \\
\hline M4-1.0 & 4.0 & 1.0 & 45.1 & 20.7 & 4.2 & 30.0 \\
\hline M4-1.5 & 4.0 & 1.5 & 43.0 & 19.8 & 7.2 & 30.0 \\
\hline M4-2.0 & 4.0 & 2.0 & 41.1 & 18.9 & 10.0 & 30.0 \\
\hline M4-2.5 & 4.0 & 2.5 & 39.4 & 18.1 & 12.5 & 30.0 \\
\hline M5-1.0 & 5.0 & 1.0 & 41.7 & 24.5 & 3.9 & 30.0 \\
\hline M5-1.5 & 5.0 & 1.5 & 39.9 & 23.4 & 6.7 & 30.0 \\
\hline M5-2.0 & 5.0 & 2.0 & 38.3 & 22.5 & 9.3 & 30.0 \\
\hline M5-2.5 & 5.0 & 2.5 & 36.8 & 21.6 & 11.7 & 30.0 \\
\hline M6-1.0 & 6.0 & 1.0 & 38.7 & 27.7 & 3.6 & 30.0 \\
\hline M6-1.5 & 6.0 & 1.5 & 37.2 & 26.6 & 6.2 & 30.0 \\
\hline M6-2.0 & 6.0 & 2.0 & 35.8 & 25.5 & 8.7 & 30.0 \\
\hline M6-2.5 & 6.0 & 2.5 & 34.5 & 24.6 & 10.9 & 30.0 \\
\hline
\end{tabular}

Physico-mechanical properties of samples were determined by methods mentioned in the Vietnam standards TCVN 6477:2011. The compressive strength R (MPa) was calculated from Eq. (1).

$$
\mathrm{R}=\frac{\mathrm{F}}{\mathrm{S}}
$$

where, $\mathrm{F}(\mathrm{N})$ is the force of breaking specimens, $\mathrm{S}\left(\mathrm{mm}^{2}\right)$ is the average value of force area of specimens.

The total shrinkage $\mathrm{T}(\%)$ was calculated from Eq. (2).

$$
\mathrm{T}=\frac{\mathrm{V}_{0}-\mathrm{V}}{\mathrm{V}_{0}} \times 100
$$

where, $\mathrm{V}_{0}$ and $\mathrm{V}\left(\mathrm{cm}^{3}\right)$ are the volume of specimen before and after curing, respectively.

The bulk density $\mathrm{D}\left(\mathrm{g} . \mathrm{cm}^{-3}\right)$ was calculated as the ratio of specimen mass $(\mathrm{m})$ to its volume $(\mathrm{V})$.

The RM was characterized by thermogravimetry (TG) and differential scanning calorimetry (DSC) using Labsys TG/DSC Setaram (France) in ambient atmosphere with the maximum temperature of $800{ }^{\circ} \mathrm{C}$, heating rate of $10^{\circ} \mathrm{C} \cdot \mathrm{min}^{-1}$.

Crystal phase of the RM, RHA and geopolymers were determined by X-ray diffraction (XRD) using Bruker D8 Advance (Germany) with $\lambda_{\text {CuK } \alpha}=1.5406 \AA$.

The chemical components of the RM and RHA were determined by the Xray Fluorescence (XRF) method using Advan't XAA173 equipment (Thermo Scientific brand). 
The particle size analysis of RM was carried out using a laser scattering particle size distribution analyzer (LA-950V2, Horiba).

The morphology of geopolymers was observed by scanning electron microscope using a Jeol JSM 5410LV and transmission electron microscope using a Jeol JEM-1010. Atomic composition of geopolymers were indicated in Energy-dispersive X-ray spectrum (EDX) using JSM Jeol 5410LV apparatus (Japan) with Oxford ISIS 300 system (England). IR spectrum of the geopolymers was analyzed on IR Prestige-21 device (Shimadzu, Japan).

\section{RESULTS AND DISCUSSION}

\subsection{Raw materials characterization}

Chemical compositions of RM and RHA are shown in Table 2. It was obvious that there were a large amount of $\mathrm{Al}_{2} \mathrm{O}_{3}$ (up to around $47 \%$ ) in $\mathrm{RM}$ and $\mathrm{SiO}_{2}$ (up to around 89 \%) in RHA. Both of main composition of RM and RHA were suitable reactants of geopolymerization reaction to produce geopolymers. Moreover, $\mathrm{Na}_{2} \mathrm{O}$ accounted for $4.4 \%$ of $\mathrm{RM}$ mass, which was the main source causing high-alkalinity in $\mathrm{RM}$ and a beneficial active agent in geopolymerization.

Table 2. The chemical components of RM and RHA.

\begin{tabular}{|c|c|c|c|c|c|c|c|c|c|c|c|}
\hline \multirow{2}{*}{$\begin{array}{c}\text { Raw } \\
\text { materials }\end{array}$} & \multicolumn{10}{|c|}{ Percentage composition (w/w) } \\
\cline { 2 - 13 } & $\mathrm{Fe}_{2} \mathrm{O}_{3}$ & $\mathrm{Al}_{2} \mathrm{O}_{3}$ & $\mathrm{SiO}_{2}$ & $\mathrm{TiO}_{2}$ & $\mathrm{Na}_{2} \mathrm{O}$ & $\mathrm{K}_{2} \mathrm{O}$ & $\mathrm{CaO}$ & $\mathrm{F}$ & $\mathrm{P}_{2} \mathrm{O}_{5}$ & $\mathrm{SO}_{3}$ & $\begin{array}{c}\mathrm{LOI} \\
\left(1000^{\circ} \mathrm{C}\right)\end{array}$ \\
\hline RM & 46.7 & 19.1 & 4.3 & 5.9 & 4.4 & 0.2 & 1.8 & 0.6 & 0.3 & 0.2 & 16.9 \\
\hline RHA & 0.2 & 0.2 & 88.4 & - & 0.2 & 3.9 & 0.8 & - & - & - & 2.0 \\
\hline
\end{tabular}

(LOI: loss on ignition)

Table 3. The $\mathrm{pH}$ value of RM.

\begin{tabular}{|c|c|c|c|c|}
\hline No. & Parameter & Unit & RM & $\begin{array}{c}\text { TCVN 7377-2004 } \\
\text { (for cultivated land) }\end{array}$ \\
\hline 1 & $\mathrm{pH}_{\mathrm{H}_{2} \mathrm{O}}$ & - & 11.35 & $4.4-6.87$ \\
\hline 2 & $\mathrm{pH}_{\mathrm{KCl}}$ & - & 11.18 & $3.73-5.82$ \\
\hline
\end{tabular}

$\mathrm{pH}$ values of $\mathrm{RM}$ in water $\left(\mathrm{pH}_{\mathrm{H}_{2} \mathrm{O}}\right)$ and in $\mathrm{KCl}$ solution $\left(\mathrm{pH}_{\mathrm{KCl}}\right)$ are presented in Table 3. The results showed that RM exhibited high alkalinity $(\mathrm{pH}>11)$ that exceeded its limitation in The Vietnamese Standards TCVN 7377-2004 for cultivated land. This could severely damage the ecosystem and cause environment pollution. This result was similar to Hai et al's report [22]. 


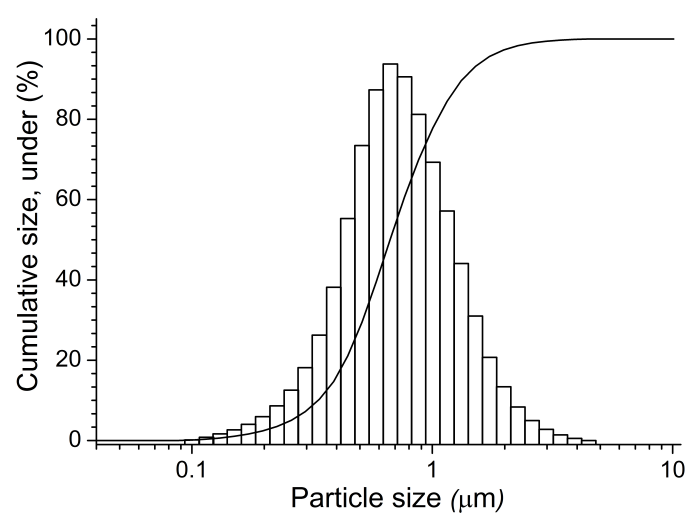

Figure 3. Particle size distribution patterns of RM.

The particle size distribution of the RM is given in Fig. 3. Mean particle size (diameters on cumulative $50 \%$ ) of the RM is $0.78 \mu \mathrm{m}$. The particle size distribution of RM varies from 0.33 $\mu \mathrm{m}$ (diameter on cumulative $10 \%$ ) to $1.33 \mu \mathrm{m}$ (mean diameter on cumulative $90 \%$ ).

XRD patterns of RM illustrated in Fig. 4A indicated a large amount of amorphous phase existing in RM. Main crystal phase of RM was observed by high intensity peaks of gibbsite $\mathrm{Al}(\mathrm{OH})_{3}$. Crystal phase of hematite $\mathrm{Fe}_{2} \mathrm{O}_{3}$ and goethite $\mathrm{FeO}(\mathrm{OH})$ were also discovered despite low intensity peaks. This demonstrated that $\mathrm{Fe}_{2} \mathrm{O}_{3}$ playing as main chemical composition of RM mainly existed in form of amorphous or microcrystal phase.

For the RHA (Fig. 4B), the amount of cristobalite $\left(\mathrm{SiO}_{2}\right)$ that was noble and harmful for geopolymerization could be observed in RHA due to the burning of rice husk at high temperature.
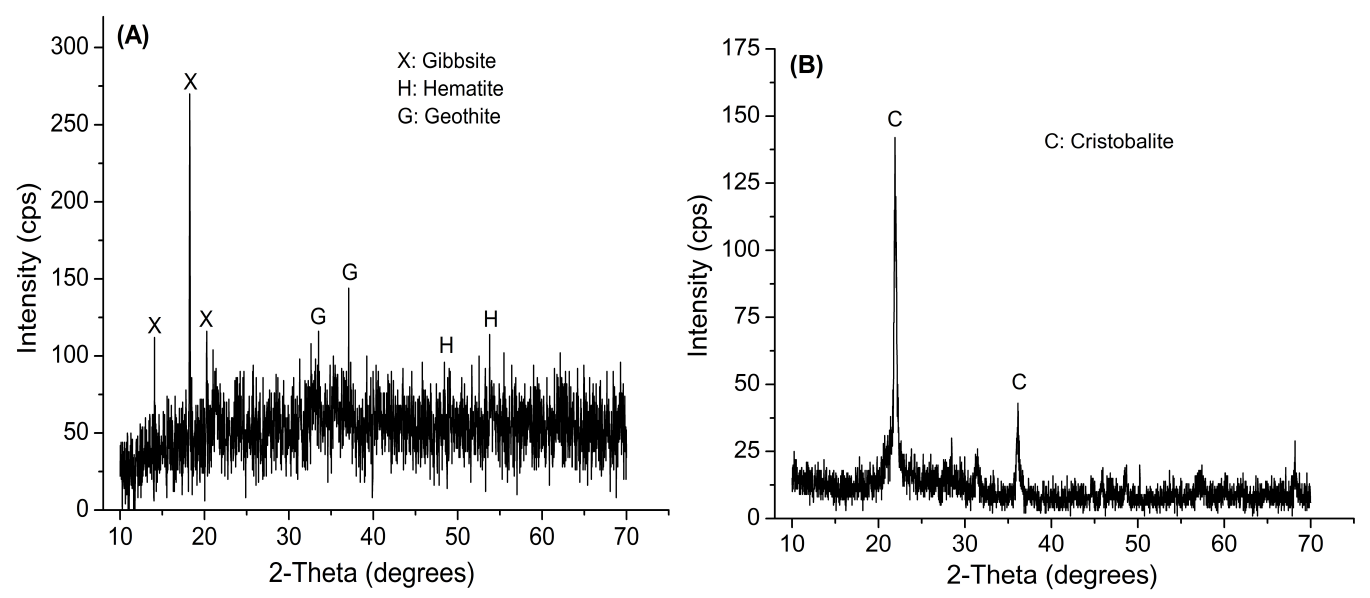

Figure 4. XRD diagram of RM (A) and RHA (B) samples.

TG-DSC diagrams of RM are presented in Fig. 5. Endothermic peak observed at $92{ }^{\circ} \mathrm{C}$ on DSC line of RM with weight loss of $3.3 \%$ are assigned to the physical water release. At 246 and $327{ }^{\circ} \mathrm{C}$, two endothermic peaks appeared with total weight loss of $13.9 \%$. This is explained by the decomposition of gibbsite, hematite and goethite minerals in RM. Finally, there is a small 
endothermic peak at $529^{\circ} \mathrm{C}$ with weight loss of $2.8 \%$ that proved the decomposition of hematite [15] as follows:

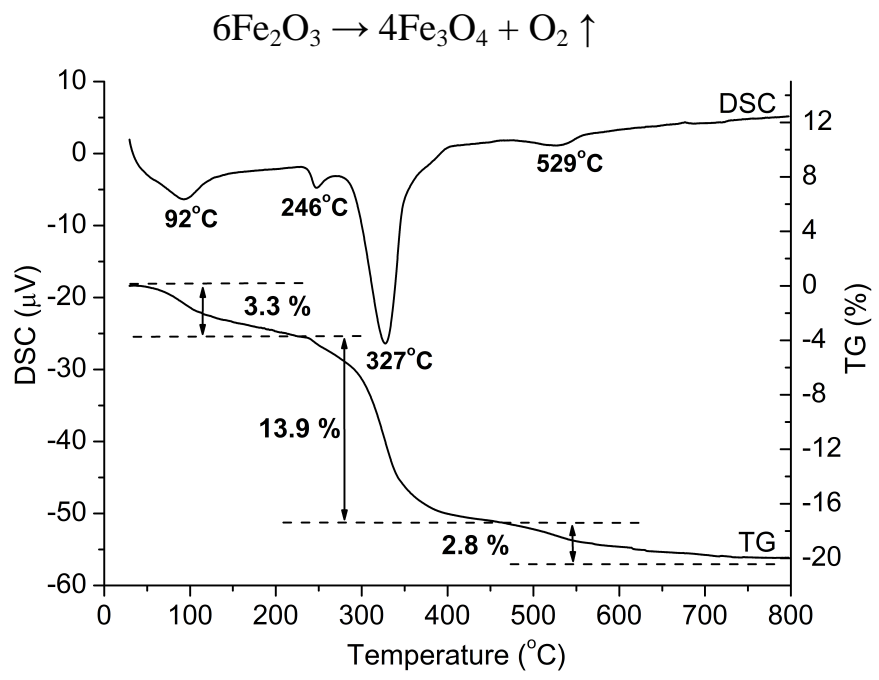

Figure 5. TG-DSC diagram of RM sample.
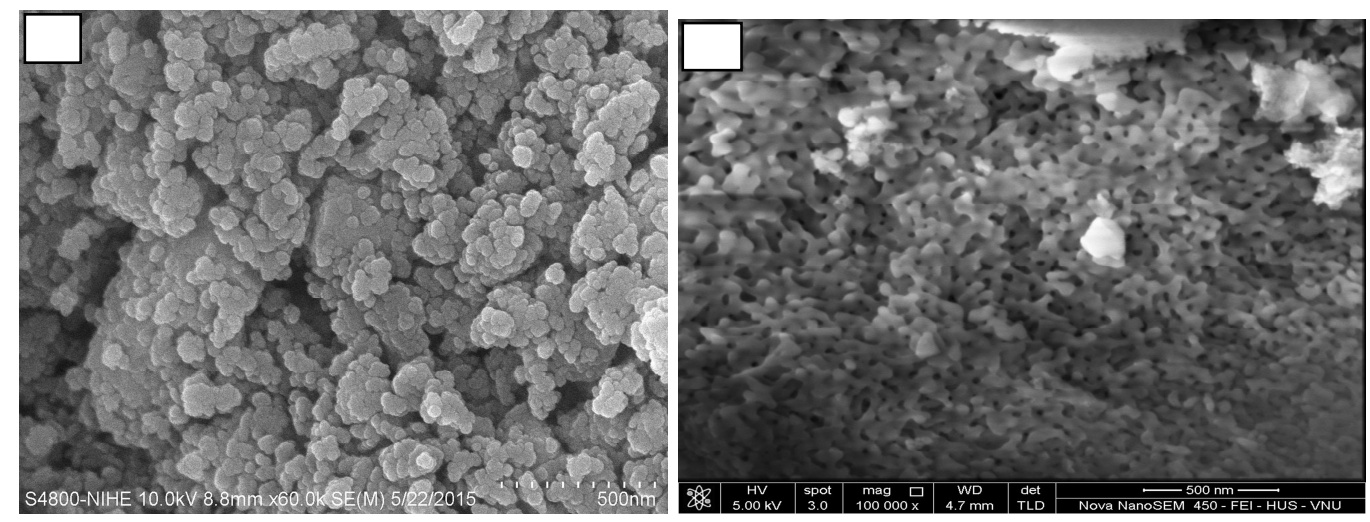

Figure 6. SEM images of RM (A) and RHA (B).

Morphology and particle size of RM and RHA are observed on the base of SEM images performed in Fig. 6. As can be seen, RM particles were rather uniform and fine, sizing from 10 to $40 \mu \mathrm{m}$, while, the structure of RHA was proved to be porous with large surface area, sizing from 80 to $100 \mathrm{~nm}$. These contributed to the enhancement of efficiency of geopolymerization between RM and RHA.

\subsection{The effect of initial composition on the physico-mechanical properties of geopolymers}

Compressive strengths of geopolymers constituted by different molar ratios of $\mathrm{SiO}_{2} / \mathrm{Al}_{2} \mathrm{O}_{3}$ and $\mathrm{Na}_{2} \mathrm{O} / \mathrm{Al}_{2} \mathrm{O}_{3}$ and at room temperature for 35 days are illustrated in Fig. 7. When the amount of $\mathrm{SiO}_{2}$ increases due to the rise of the amount of RHA, the efficiency of geopolymerization is enhanced and this results in the uptrend of compressive strength value. This is demonstrated in the range of $\mathrm{SiO}_{2} / \mathrm{Al}_{2} \mathrm{O}_{3}$ molar ratio from 3 to 4 . However, when $\mathrm{SiO}_{2} / \mathrm{Al}_{2} \mathrm{O}_{3}$ molar ratio values are more than 4 , compressive strength of samples decreases. This might be because the 
redundant amount of $\mathrm{SiO}_{2}$ plays as impurity that badly impact to the quality of samples and the geopolymerization gets equilibrium at $\mathrm{SiO}_{2} / \mathrm{Al}_{2} \mathrm{O}_{3}$ molar ratio of 4 .

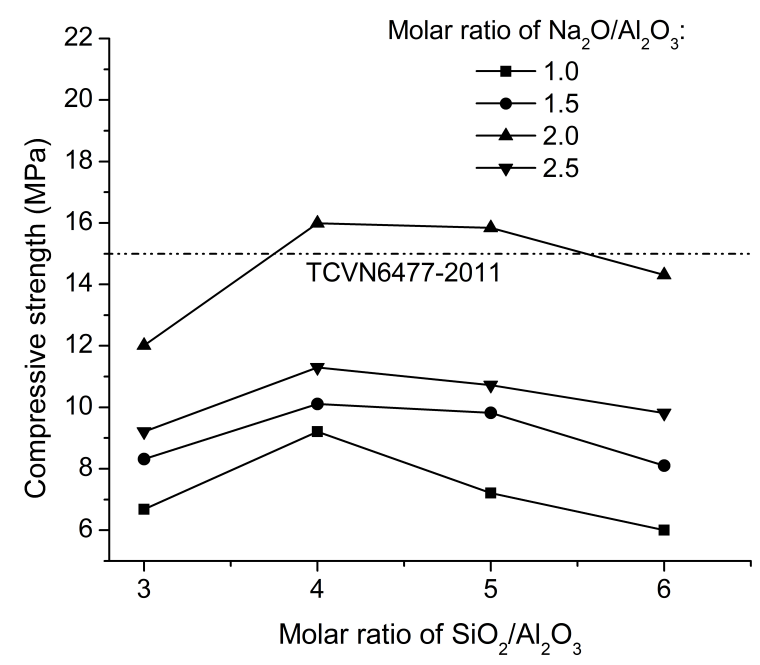

Figure 7. Effect of initial compositions on compressive strength of geopolymers at a curing time of 35 days.

When fixing $\mathrm{SiO}_{2} / \mathrm{Al}_{2} \mathrm{O}_{3}$ molar ratio, the increase of $\mathrm{Na}_{2} \mathrm{O} / \mathrm{Al}_{2} \mathrm{O}_{3}$ molar ratio from 1 to 2 made the compressive strengths of geopolymers surge remarkably. Samples prepared with $\mathrm{Na}_{2} \mathrm{O} / \mathrm{Al}_{2} \mathrm{O}_{3}$ molar ratio of $2, \mathrm{SiO}_{2} / \mathrm{Al}_{2} \mathrm{O}_{3}$ molar ratios of 4 and 5 , exhibited the value of compressive strengths that met the Vietnam standard TCVN 6477-2011 for unsintered bricks using for construction. When increasing $\mathrm{Na}_{2} \mathrm{O} / \mathrm{Al}_{2} \mathrm{O}_{3}$ molar ratio to 2.5 , the mixture became too doughy that caused difficulty in shaping and some cracks were found on the surface of dry samples. Therefore, the proper $\mathrm{Na}_{2} \mathrm{O} / \mathrm{Al}_{2} \mathrm{O}_{3}$ molar ratio was 2.0. This survey proved an important role of $\mathrm{NaOH}$ in geopolymerization between RM and RHA and the mechanism of this process was predicted as follows [1, 4]:

$$
\begin{aligned}
& \mathrm{nAl}_{2} \mathrm{O}_{3}+4 \mathrm{nSiO}_{2}+7 \mathrm{nH}_{2} \mathrm{O}+2 \mathrm{NaOH} \longrightarrow 2\left[\left(\mathrm{Na}^{+}\right)\left((\mathrm{OH})_{3}-\mathrm{Si}-\mathrm{O}-\stackrel{(-)}{\mathrm{Al}}-\mathrm{O}-\mathrm{Si}-(\mathrm{OH})_{3}\right)_{\mathrm{n}}\right] \\
& \text { (Geopolymer precursor) }
\end{aligned}
$$

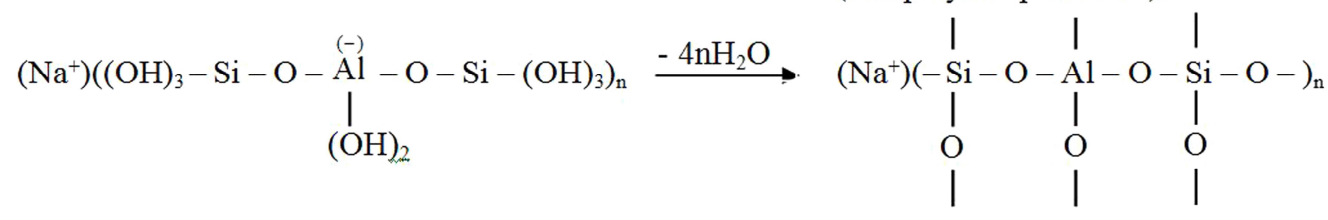

\subsection{The effect of curing temperature and time on the physico-mechanical properties of geopolymers}

From the above results, the suitable molar ratios of initial material for producing geopolymers were $\mathrm{Na}_{2} \mathrm{O} / \mathrm{Al}_{2} \mathrm{O}_{3}$ of 2.0 and $\mathrm{SiO}_{2} / \mathrm{Al}_{2} \mathrm{O}_{3}$ of 4 . In order to infer the effect of curing temperature and time on the physico-mechanical properties of the obtained geopolymers, samples were prepared with the same constituents of initial material at different temperatures and times. The changes of compressive strength of samples were represented in Fig. 8. 
According to Fig. 8A, at room temperature, almost values of compressive strength of geopolymers cured for different times were rather low and lower than the standard value of TCVN 6477-2011 until 35 days. This result was similar to the Kumar's report of producing geopolymers from RM and fly ash [10].

Figure 8B showed the changes of compressive strength of samples cured at different temperatures from 50 to $200{ }^{\circ} \mathrm{C}$ for different curing times. As can be seen, the higher curing temperature was, the shorter curing time was, i.e., at 50; $100 ; 150$ and $200{ }^{\circ} \mathrm{C}$, the compressive strength of samples met TCVN 6477-2011 after about 24; 12; 8; 4 hours for curing, respectively. Among the surveyed temperatures, at $100{ }^{\circ} \mathrm{C}$, the maximum value of compressive strength was about $33.4 \mathrm{MPa}$ after 72 hours and higher than that at remaining temperatures. However, 24 hours was still enough for curing samples that exhibited compressive strength (22.8 MPa) met the TCVN 6477-2011. Under strong effect of high temperature, e.g., 150 and $200{ }^{\circ} \mathrm{C}$, many cracks were observed on the surface of samples, thus, the maximum value of compressive strength (only around $30 \mathrm{MPa}$ ) was smaller than that at $100{ }^{\circ} \mathrm{C}$.
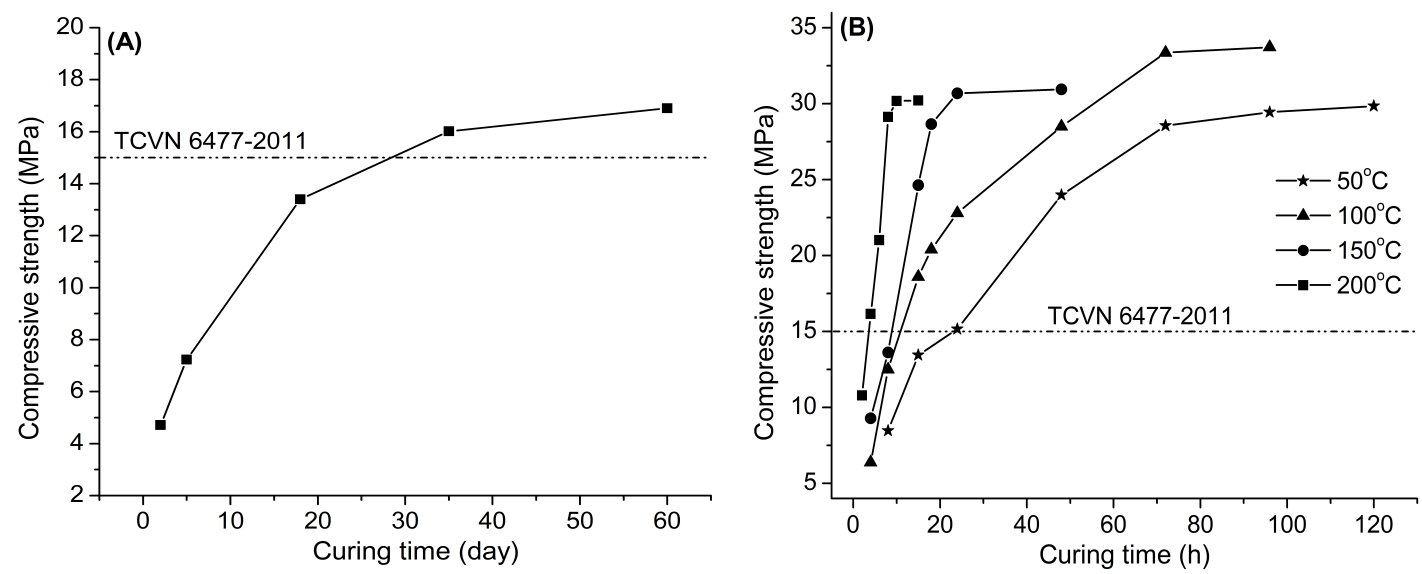

Figure 8. Compressive strength of geopolymers cured at room temperatures (A) and high temperatures (B) for different curing times.
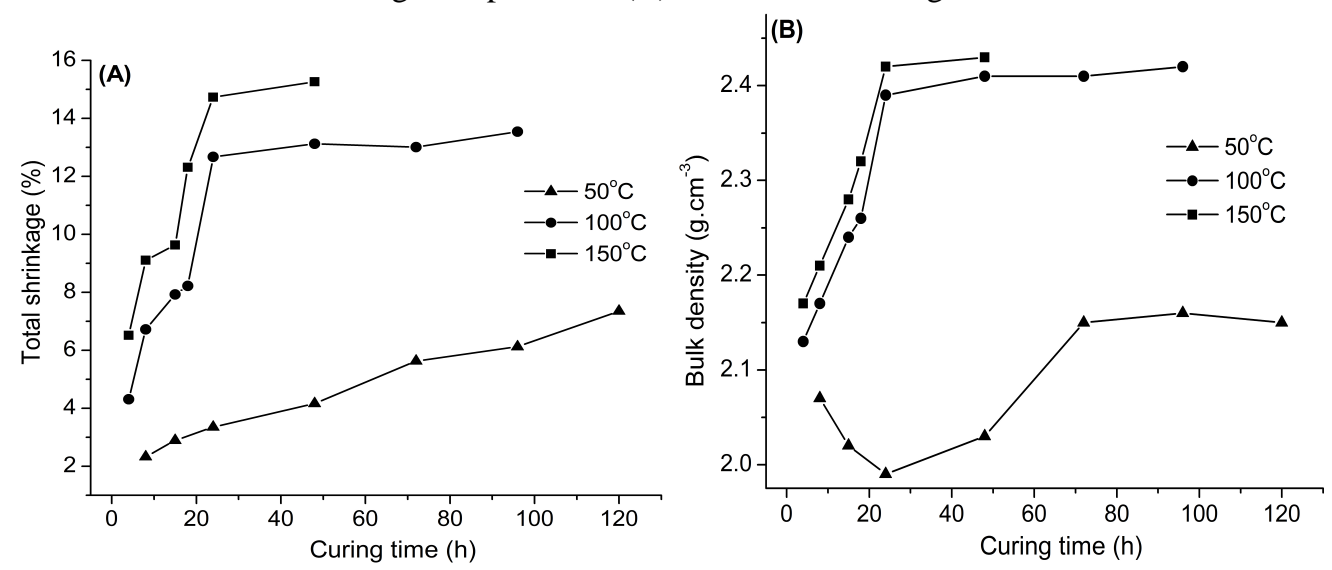

Figure 9. Total shrinkage (A) and bulk density (B) of geopolymers cured at different temperatures and times.

Total shrinkages and bulk density of geopolymers prepared at different curing temperatures for different times were illustrated in Fig. 9. In general, for the same curing time, total shrinkage 
and bulk density values of samples prepared at $50{ }^{\circ} \mathrm{C}$ were always much lower than those at other curing temperatures. At 100 and $150{ }^{\circ} \mathrm{C}$, these properties of samples increase strongly, when curing time rises from 12 to 24 hours. After 24 hours, total shrinkage and bulk density values of geopolymers seem to be unchanged. The maximum value of total shrinkage and bulk density of geopolymers at $100{ }^{\circ} \mathrm{C}$ were nearly $13 \%$ and 2.4 g.cm ${ }^{-3}$.

In conclusion, the higher curing temperature and longer curing time were, the higher physico-mechanical properties of samples were. That was because at high temperature and for long time, the amount of water released from the formation of bonding between - $\mathrm{Al}-\mathrm{OH}$ and -Si$\mathrm{OH}$ groups was large, thus, the efficiency of geopolymerization between $\mathrm{Al}_{2} \mathrm{O}_{3}$ and $\mathrm{SiO}_{2}$ was enhanced [23]. For the purpose of saving energy and time, $100{ }^{\circ} \mathrm{C}$ and 24 hours seem to be suitable for geopolymerization between RM and RHA, the physico-mechanical properties of obtained geopolymers met TCVN 6477-2011.
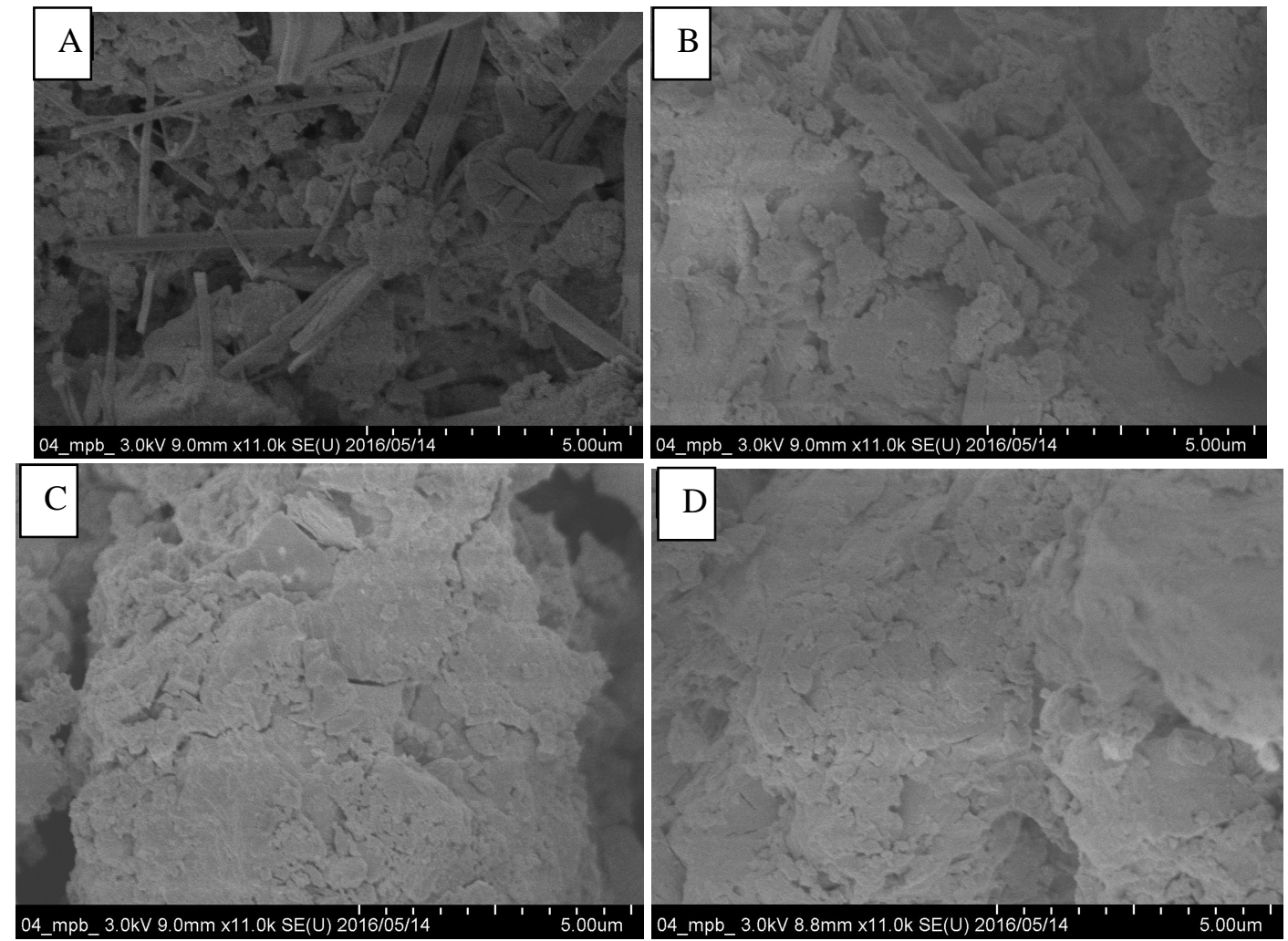

Figure 10. SEM images of M4-2.0-100-12 (A), M4-2.0-100-24 (B), M4-2.0-100-36 (C), and M4-2.0-100-72 (D) samples.

The surface morphology of geopolymers cured at $100{ }^{\circ} \mathrm{C}$ for different times from 12 to 72 hours (notated from M4-2.0-100-12 to M4-2.0-100-72) was observed on the basis of SEM images shown in Fig. 10. As can be seen, the increase of compact degree of samples was followed by the intensification of curing time, i.e., after 12 hours for curing sample, samples structure was still porous, contained many empty holes and rod crystallites that were disappeared in structure of samples cured for longer times (24 to 72 hours). These remarks get agreement with the variation of physico-mechanical properties of product learned from above investigations. Yet again, this confirmed the suitable conditions for manufacturing geopolymers were $\mathrm{SiO}_{2} / \mathrm{Al}_{2} \mathrm{O}_{3}$ molar ratio of $4, \mathrm{Na}_{2} \mathrm{O} / \mathrm{Al}_{2} \mathrm{O}_{3}$ molar ratio of 2.0 ; curing temperature of $100{ }^{\circ} \mathrm{C}$ and curing time of 24 hours (sample M4-2.0-100-24). 


\subsection{Characterization of geopolymers}

EDX diagram of M4-2.0-100-24 was shown in Fig. 11. Obviously, main constituents of sample were $\mathrm{SiO}_{2}, \mathrm{Fe}_{2} \mathrm{O}_{3}, \mathrm{Al}_{2} \mathrm{O}_{3}, \mathrm{Na}_{2} \mathrm{O}, \mathrm{K}_{2} \mathrm{O}, \mathrm{TiO}_{2}, \mathrm{CaO}$, which were common oxides in initial materials (RM and RHA). The proportions of its atomic compositions were similar to those in the initial materials.

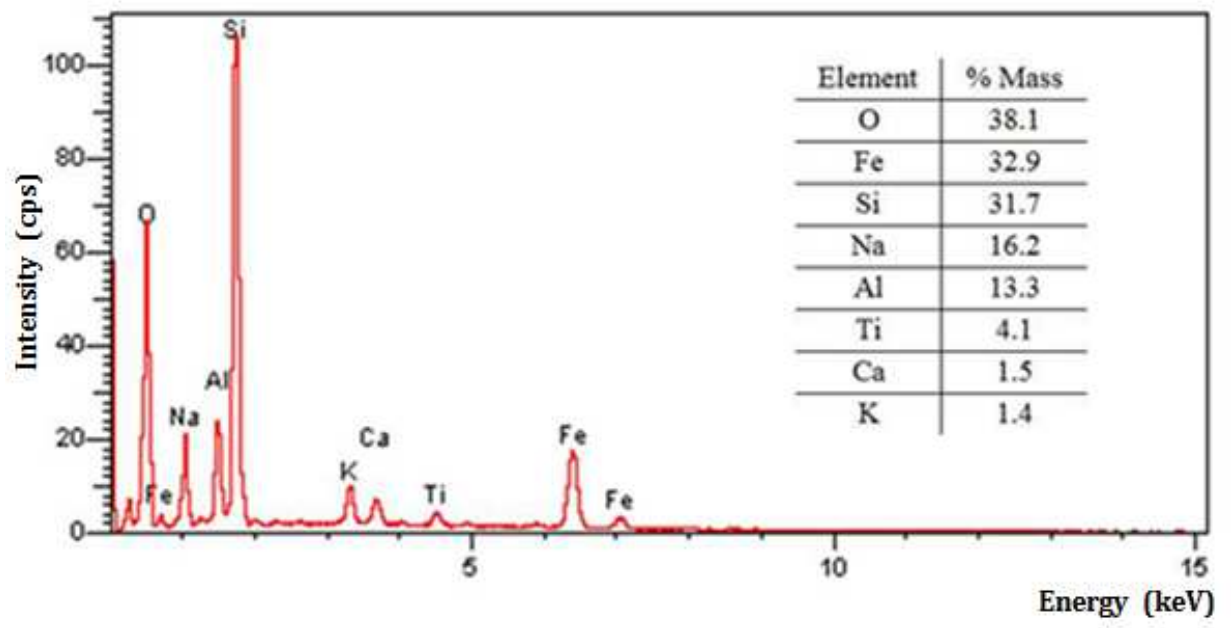

Figure 11. EDX diagram of M4-2.0-100-24 sample.

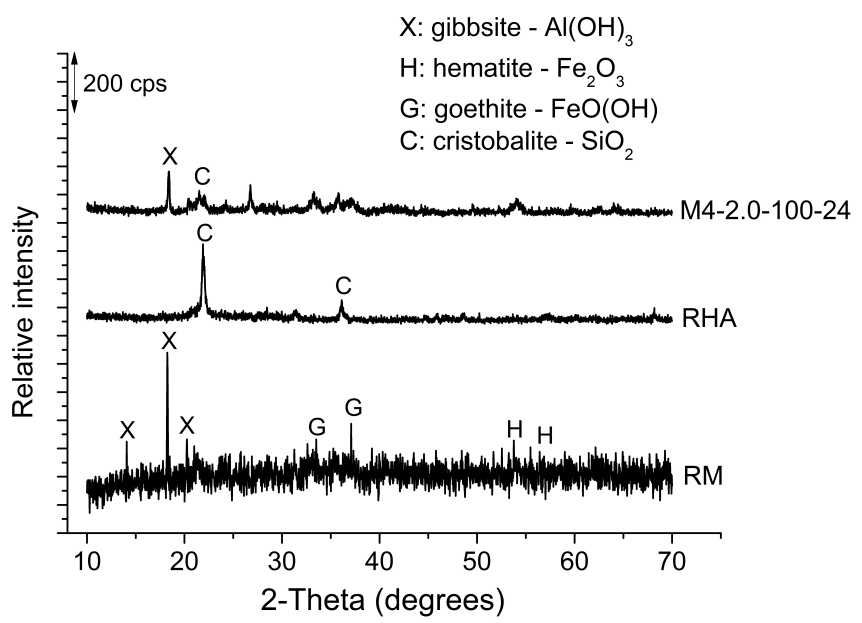

Figure 12. XRD diagrams of RM, RHA and M4-2.0-100-24 sample.

The difference of crystal phase compositions between RHA, RM and M4-2.0-100-24 sample was revealed in XRD diagram shown in Fig. 12. Peaks' intensity of main crystal phases of initial materials (RM and RHA), i.e., gibbsite $\left(\mathrm{Al}(\mathrm{OH})_{3}\right)$, cristobalite $\left(\mathrm{SiO}_{2}\right)$, geothite $(\mathrm{FeO}(\mathrm{OH}))$, were significantly lessened in XRD line of M4-2.0-100-24 sample. This meant the reaction between $\mathrm{SiO}_{2}$ and $\mathrm{Al}(\mathrm{OH})_{3}$ took place nearly completely to form geopolymers. 


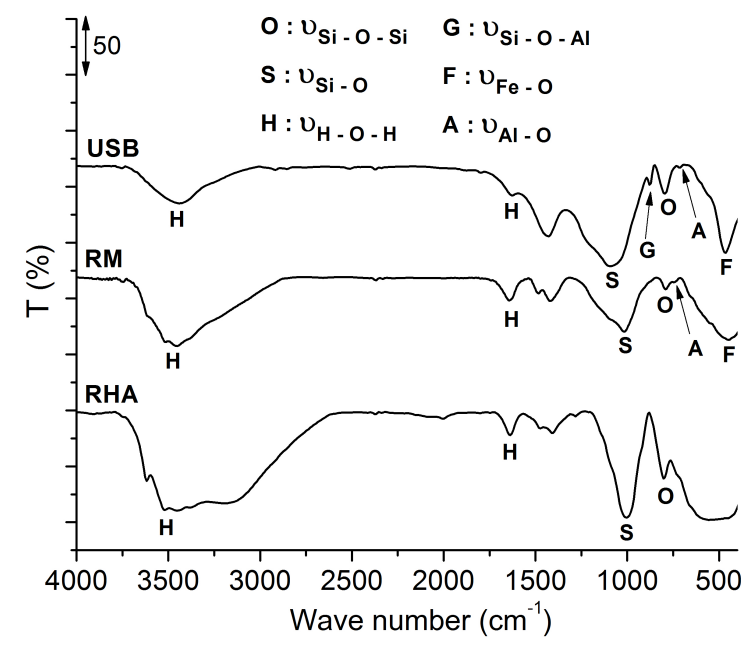

Figure 13. FTIR spectra of M4-2.0-100-24 sample.

Group characterization of RHA, RM and M4-2.0-100-24 (donated USB) samples were determined by FTIR study as shown in Fig. 13. A broad bands in the region $3510-3400 \mathrm{~cm}^{-1}$ assigned to $-\mathrm{OH}$ stretching vibration of interlayer adsorbed $\mathrm{H}_{2} \mathrm{O}$ molecules, while, band in 1640$1600 \mathrm{~cm}^{-1}$ is attributed to $\mathrm{H}-\mathrm{O}-\mathrm{H}$ bending vibration. $\mathrm{Si}-\mathrm{O}$ vibration and $\mathrm{Si}-\mathrm{O}-\mathrm{Si}$ asymmetric stretching mode were detected by bands at wavenumber of 1018-1000 $\mathrm{cm}^{-1}$ and 810-790. Stretching vibration of $\mathrm{Al}-\mathrm{O}$ corresponding with peak at $708 \mathrm{~cm}^{-1}$ was both appeared in RM and USB sample. The proof of geopolimerization between RM and RHA was exhibited at peak at $875 \mathrm{~cm}^{-1}$ corresponding with Si-O-Al vibration only appearing in FT-IR of USB sample [10, 23, 24].

\section{CONCLUSIONS}

Geopolymers was successfully synthesized from RM and RHA under the most appropriate conditions that were: (i) initial material compositions were RM, RHA and $\mathrm{NaOH}$ with $\mathrm{SiO}_{2} / \mathrm{Al}_{2} \mathrm{O}_{3}$ molar ratio of 4 and $\mathrm{Na}_{2} \mathrm{O} / \mathrm{Al}_{2} \mathrm{O}_{3}$ molar ratio of 2.0 ; (ii) curing temperature of $100^{\circ} \mathrm{C}$; (iii) curing time of 24 hours. The physico-mechanical properties including compressive strength, total shrinkage and bulk density of obtained product were $22.8 \mathrm{MPa}, 2.39 \mathrm{~g} . \mathrm{cm}^{-3}, 15 \%$, respectively, that met the standard for unsintered brick using for construction.

Acknowledgements: This research was financially supported by the project of Vietnam Ministry of Education and Training: "Development building brick from red mud derived from the aluminum industry", Code B2016-DHH-09.

\section{REFERENCES}

1. Khale D., Chaudhary R. - Mechanism of geopolymerization and factors influencing its development: a review, Journal of Materials Science 42 (2013) 729-746.

2. Duxson P., Fernandez-Jimenez A., Provis J. L., Lukey G. C., Palomo A., Van Deventer J. S.J. - Geopolymer technology: the current state of the art, Journal of Materials Science $\mathbf{4 2}$ (2007) 2917-2933. 
3. Hajjaji W., Andrejkovicova S., Zanelli C., Alshaaer M., Dondi M., Labrincha J. A., Rocha F. - Composition and technological properties of geopolymers based on metakaolin and red mud, Materials \& Design 52 (2013) 648-654.

4. Wang J., Zhang C., Xu J., Qu P., Zhou Y., Min H.H. - The effect of alkali on compressive of metakaolin based geopolymeric cement, Advanced Materials Research 554-556 (2012) p. 327-330.

5. Kim D., Lai H. T., Chilingar G. V., Yen T. F. - Geopolymer formation and its unique properties, Environmental Geology 51 (2006) 103-111.

6. Choo H., Lim S., Lee W., Lee C. - Compressive strength of one-part alkali activated fly ash using red mud as alkali supplier, Construction and Building Materials 125 (2016) 21-28.

7. He H., Yue Q., Qi Y., Gao B. - The effect of incorporation of red mud on the properties of clay ceramic bodies, Applied Clay Science 70 (2012) 67-71.

8. He J., Jie Y., Zhang J., Yu Y., Zhang G. - Synthesis and characterization of red mud and rice husk ash-based geopolymer composites, Cement and Concrete Composites 37 (2013) $108-118$.

9. Kaya K., Soyer-Uzun S. - Evolution of structural characteristics and compressive strength in red mud-metakaolin based geopolymer systems, Ceramics International 42 (2016) 7406-7413.

10. Kumar A., Kumar S. - Development of paving blocks from synergistic use of red mud and fly ash using geopolymerization, Construction and Building Materials 38 (2013) 865-871.

11. Yang J., Xiao B. - Development of unsintered construction materials from red mud wastes produced in the sintering alumina process, Construction and Building Materials 22 (2008) 2299-2307.

12. Ye N., Yang J., Liang S., Hu Y., Hu J., Xiao B., Huang Q. - Synthesis and strength optimization of one-part geopolymer based on red mud, Construction and Building Materials 111 (2016) 317-325.

13. Li X., Xiao W., Liu W., Liu G., Peng Z., Zhou Q., Qi T. - Recovery of alumina and ferric oxide from Bayer red mud rich in iron by reduction sintering, Transactions of Nonferrous Metals Society of China 19 (2009) 1342-1347.

14. Altundogan H. S., Altundogan S., Tumen F., Bildik M. - Arsenic removal from aqueous solutions by adsorption on red mud, Waste Manage 20 (2000) 761-767.

15. He H., Yue Q. - Preparation and mechanism of the sintered bricks produced from Yellow River silt and red mud, Journal of Hazardous Materials 203-204 (2013) 53-61.

16. Jayasankar K., Ray P. K., Chaubey A. K., Padhi A., Satapathy B. K., Mukherjee P. S. Production of pig iron from red mud waste fines using thermal plasma technology, International Journal of Minerals Metallurgy and Materials 19 (2012) 679-684.

17. Liu W., Yang J., Xiao B. - Application of Bayer red mud for iron recovery and building material production from alumosilicate residues, Journal of Hazardous Materials 161 (2009) 474-478.

18. Leonardou S. A., Oustadakis P., Tsakiridis P. E., Markopoulos C. - Titanium leaching from red mud by diluted sulfuric acid at atmospheric pressure, Journal of Hazardous Materials 157 (2008) 579-586. 
19. Pera J., Boumaza R., Ambroise J. - Development of a pozzolanic pigment from red mud, Cement and Concrete Research 27 (1997) p.1513-1522.

20. Petropulu M.O., Lyberopulu T., Ochsenkiihn K.M., Parissakis G. - Recovery of Lanthanides and Yttrium from red mud by selective leaching, Analytica Chimica Acta 319 (1996) p. 249-254.

21. Tsakiridis P.E., Leonardou S.A., Oustadakis P. - Red mud addition in the raw meal for the production of Portland cement clinker, Journal of Hazardous Materials B116 (2004) p. 103-110.

22. Hai L.D., Khai N.M., Quy T.V., Huan N.X. - Material composition and properties of red mud coming from alumina processing plant Tanrai, Lamdong, Vietnam, International Journal of Research in Earth and Environmental Sciences 1 (2014) p. 1-7.

23. Lemougna P.N., Wang K., Tang Q., Cui X. - Synthesis and characterization of low temperature $\left(<800^{\circ} \mathrm{C}\right)$ ceramics from red mud geopolymer precursor, Construction and Building Materials 131 (2017) p. 564-573.

24. Gangwar J., Gupta B.K., Kumar P., Tripathi S.K., Srivastava A.K. - Time-resolved and photoluminescence spectroscopy of $\theta-\mathrm{Al}_{2} \mathrm{O}_{3}$ nanowires for promising fast optical sensor applications, Dalton Transactions 43 (2014) p. 17034-17043. 